\title{
Competitiveness of Price in International Road Freight Transport
}

\section{- Milos Poliak, Adela Poliakova, Lucia Svabova, Natalia Aleksandrovna Zhuravleva, Elvira Nica}

\begin{abstract}
Over the last 30 years, the competition in road transport has increased significantly. For a transport company to maintain its position in the road freight transport market, the knowledge of the accurate costs arising from the transportation process is an important tool in the current competitive struggle. Carriers quantify the transportation costs in the process of price creation using the routes utilization coefficient, also taking into account routes with an empty vehicle. The value is usually set as a constant in the range from 0 to 1 . The purpose of this paper is to show that it is more appropriate and economically feasible to consider this as a variable which depends on the direction as well as on the time of the transportation. In this analysis, a twofactor ANOVA model was applied to actual data of transport offers to Slovakia from 18 different countries recorded on a daily basis in a period of one year. The analysis shows that the direction of transportation is a significant factor in the offer, and therefore it is appropriate to include this factor in the price creation. The results of this analysis are in practice directly applicable to modify the calculation procedures and thus gain a competitive advantage for the transport operator in calculating the transportation price. Using this methodology, the carrier can determine the price more accurately and achieve greater price competitiveness in road transport in the common EU market.
\end{abstract}

Keywords: competitiveness, transport, coefficient, calculation, costs

JEL Classification: R48, H40

Received: May, 2020

1st Revision: April, 2021

Accepted: April, 2021

\section{INTRODUCTION}

Over the last 30 years, competition in road transport has increased significantly, with the road freight transport market characterized by high competition among individual carriers. Although the costs of transport operators have also increased significantly, the price for transportation has not corresponded to an increase in costs (Ross, 2015; Rushton et al., 2010). In fact, price increases for transportation are growing at a significantly slower rate as compared to the growth of costs. This situation has led several carriers to breach EU legislation by subcontracting (Rotondo, 
2013). Carriers have thus sought to gain a competitive advantage by violating legal regulations (Osterloh \& Heinemann, 2013). The EU has amended the rules to ensure a fair market (Regulation 2020/1054). However, the competition remains strong. The price for transportation within the EU remained almost unchanged between 2000 and 2019 (Ferrari, 2016; Jourquin, 2019), whereas costs have changed significantly, in particular, labour, toll, and fuel costs. Transport operators seeking to gain a competitive advantage by optimizing costs (Krasnyanskiy \& Penshin, 2016) need to increase the efficiency of the provision of transportation in order to remain on the market (Avetisyan et al., 2015). They utilise cost calculations dividing costs into variable and fixed costs. Transportation-only costs are calculated for transportation separately (Ferrari, 2016; Kovacs, 2017). However, costs are modified via the route utilization coefficient, the aim of which is to adjust costs so that unladen routes are also included in the costs. The route utilization coefficient has a constant value determined for a particular vehicle in the range from 0 to 1 (Engholm et al., 2020; Lada et al., 2016). For a vehicle that transports milk from a farm to a dairy, for instance, it is not possible to transport other goods on the way back, e.g. oil. Such a vehicle will drive back empty, while the customer only pays for one-way transportation. The costs in one direction are therefore divided by a coefficient of 0.5 in order to cover the return trip as well. But if the carrier is able to utilize at least a part of the return trip, the coefficient increases, and thus the competitive advantage for the carrier also increases. Currently, a constant value of this indicator is usually used in calculation tools (Lada et al., 2016).

The purpose of this research paper is to verify that from the point of view of the competitiveness of price creation in road transport, it is not economically feasible to use the route utilization coefficient as a constant value. Moreover, the aim of the study is also to verify the hypothesis that it is appropriate and more economically feasible in terms of considering the route utilization coefficient as a variable, depending on the direction of the transportation as well as on the time of the transportation during the week. The main contribution of this paper is the verification of the variability of the route utilization coefficient based on actual data on transport offers to Slovakia from 18 different countries. The data comes from the largest transport database, Timocom, recorded on a daily basis within the period of one year. The study focuses on the analysis of the dependence of transport offers to Slovakia on the factors of country direction and the day of the week, but it can be assumed that similar results would be shown in an analysis focused on transport offers to another country. The utilization coefficient defined in this study would provide carriers with a competitive advantage in that they would be able to accurately determine the level of costs for each transportation offer. Since such an approach to the determination of the route utilization coefficient has not yet been published in studies by other authors, the research in this paper can be considered innovative in this respect. The results of the study could have a significant impact on competitiveness in the transport sector.

The paper consists of four chapters. The literature review describes the current state of the issue of cost calculation in road freight transport. Based on the scientific outcomes of other authors, approaches to cost calculation currently in use are identified. The chapter on data and methodology identifies the importance of the route utilization coefficient as well as characterizes the data sources of the transport databases used for the research. In the results and discussion chapter, the established hypotheses regarding the variability of the route utilization coefficient depending 
on the destination country and the day of the week are verified. In the final part of the paper, the conclusions of the analysis are confronted with the conclusions of other authors, and a possible further direction of this research study is suggested.

\section{LITERATURE REVIEW}

In doing business in road transport with economically feasible calculations, it is necessary to take a special approach to fixed and variable costs (Jourquin \& Beuthe, 2019). Such an approach to price creation calculation is necessary, which is a condition stated in the studies of e.g., Forootani et al. (2019), McLennan (1984), Vaishya \& Sarkar (2019), Gnap (2002). Even so, in road freight transport the route utilization coefficient must also be taken into account. The development of calculation methods has been discussed by several authors, for example, Drozdziel \& Piasecki (1995), Gnap (2002), Baller et al. (2019), Lai (2010), Poliak (2013), Turner \& Park (2008), Xie \& Wang (2018). From the point of view of competitiveness, it is necessary to apply an economically feasible cost calculation (Valaskova et al., 2018, (Svabova \& Durica, 2016), which is a prerequisite for the solid decision-making by the entrepreneur in setting the price for the provision of a respective service (Kliestik et al., 2018; Svabova et al., 2020). Several authors have stated that corporate taxation must also be considered (Gnap et al., 2018; Osterloh \& Debus, 2012; Osterloh \& Heinemann, 2013).

Transport is specific because it also accomplishes a performance that is not directly included in the price of goods (Kovacs, 2017). Lada et al. (2016) point out that the vehicle not only accomplishes the performance with the load but also performs the vehicle transfer from the place of unloading the consignment to a place of loading the consignment for the subsequent transportation. To ensure the effectiveness of the transport for the carrier along with price competitiveness of the transport, it is also necessary to include these costs of such transfers in the customer's price for the provided transportation of consignments. According to the calculation methods described by Kedzior-Laskowska (2019), Lai (2010), Poliak (2013) and Rothengatter (2019), the variable costs for specific transportation are modified by the routes utilization coefficient as follows

$$
V C_{T}=\left(f\left(v c_{T} ; d_{T}\right)\right) / K \text {, }
$$

where $\mathrm{Vc}_{\mathrm{T}}$ are the transportation-related costs variable which is a function of the unit variable costs per kilometre $\mathrm{vc}_{\mathrm{T}}$ and the distance travelled during the transportation $\mathrm{d}_{\mathrm{T}}$, adjusted by the route utilization coefficient $\mathrm{K}$ which expresses what proportion of the total distance travelled will be used by the carrier for the transportation. The value of the route utilization coefficient $\mathrm{K}$ has been determined by several authors as a constant. For example, Bokor \& Markovits-Somogyi (2015) state in their study that for a tank vehicle that returns empty, the value of this coefficient is 0.5. As reported by Bao \& Mundy (2018), Drozdziel \& Piasecki (1995), Gnap (2002) or Engholm et al. (2020), for international transport a value of the route utilization coefficient $\mathrm{K}$ in the range of 0.8 to 0.9 is recommended. The coefficient does not adjust the fixed transport costs $\left(\mathrm{FC}_{\mathrm{T}}\right)$, which are given by the formula

$F C_{T}=f\left(f c_{D} ; n\right)$,

where $\mathrm{fc}_{\mathrm{D}}$ are the fixed costs per one day of operation of the vehicle and $\mathrm{n}$ is the number of days of transportation. 
The number of days of transport is indicated in formula (2) by $\mathrm{n}$ and means the number of days that a particular one transport lasts (for which an invoice is issued). Then, the number of days of operation per year, i.e. how many days per year (out of 365 days) the vehicle works, is denoted by $\mathrm{D}_{\mathrm{V}}$, used in the following formula (3).

Given that the vehicle does not operate every day of the year, it can be argued that the fixed costs per one day of operation $\mathrm{nf}_{\mathrm{D}}$ are a function of the fixed costs per year per vehicle $\mathrm{Fc}_{\mathrm{Y}}$ and the number of days of operation of the vehicle per year $\mathrm{D}_{\mathrm{v}}$. That is, the fixed costs per one transportation depend on the calculation methods currently used as follows

$F C_{T}=f\left(F C_{Y} ; D_{V} ; n\right)$.

Gnap et al. (2018) note that most transport companies only record their internal costs incurred in the course of their business, whereas they do not consider external costs, which they are unable to quantify from the accounts. Trigaux et al. (2017) state that these costs arise due to the performing transportation services, e.g. costs of infrastructure, environmental protection costs, etc., and are paid in most cases by the state. However, this study will not deal with these costs further, as these costs without their internalisation do not affect the costs of the carrier in particular transportation. Also, the impact of the quality of the transportation service, which also significantly affects the competitiveness of the transport operator, will not be taken into account further in this study. The relationship between the quality and competition of transport services is discussed, for example, by Askari \& Peiravian (2019), Gasparik et al. (2015), Jourquin (2019), Litman (2019).

Based on the literature review, it can be stated that several authors deal with calculations and the method of counting return transportation. In contrast, they determine this recalculation using a constant value of the coefficient $\mathrm{K}$. However, with the advent of more powerful computer technology, it is possible to monitor the route utilization coefficient $\mathrm{K}$ in more detail and determine it more precisely in the form of a variable. This approach to price creation cannot yet be found in studies published by other authors so far.

\section{RESEARCH OBJECTIVE, METHODOLOGY AND DATA}

The research objective of this paper is the route utilization coefficient which significantly affects the calculated costs for particular transportation in road freight transport. From the point of view of maintaining the company's position on the road freight transport market, the knowledge of the accurate costs that arise during the transportation is an important tool for the carrier in the current competitive struggle. Based on the results of the studies by Albalate et al. (2015) and Mitsakis et al. (2015), in Europe, there are significantly higher east-west traffic flows in comparison with north-south routes. That means, if transportation performed from Central Europe was terminated in Southern Europe (e. g. Serbia), the carrier would be less likely to obtain transportation back, compared to the transportations terminated in Western Europe (e. g. Germany). Based on this assumption, the purpose of this research is to verify the hypothesis that the route utilization coefficient is a variable, depending on the transportation routing. Within the EU, in the form of social law (Regulation 2020/1054), rest in the vehicle is limited during the weekend, so it can be assumed that more carriers will be willing to take over a consignment 
for transportation at the beginning of the week compared to the end of the week. Based on this assumption, the second aim of this analysis is to verify the hypothesis that the route utilization coefficient depends on the day on which the transportation is commenced.

In order to be able to identify a change in the routes utilization coefficient in connection with a change in the direction of the transportation and to avoid as much as possible the specific influence of respective regions, this study used data published by transport databanks to identify a change in demand, given that, in most cases, carriers use these transport databanks in search for return transportation services (Nowak et al., 2019). A transport databank is a virtual place where the demand and supply of transportation in road transport meet, i.e. a database of transport demand for unoccupied consignments for ride and offers of accessible vehicles to which transportation is not assigned. We used data from the largest transport databank, Timocom, in which 43,000 companies from Europe are registered, and the database processes on average 750,000 transportations per day across the whole Europe (Timocom, 2020). Since the Timocom transport databank does not archive the current status of vehicle offers and free transportation offers between every two countries in the databank every day, we downloaded the data separately on every calendar day during the research, focusing on data on transport offers to Slovakia. The research lasted from 1 September 2018 to 31 August 2019, during which we identified the proportion of offered free transportations to Slovakia in the transport databank and the proportion of offered accessible vehicles for transportation services. In order to verify the variability in the development of the route utilization coefficient, it is sufficient to focus the research only on return transportations to one country. Therefore, the study is aimed at the supply of the return transportations to Slovakia from the following countries: Belgium, Bulgaria, the Czech Republic, France, the Netherlands, Luxembourg, Hungary, Germany, Poland, Austria, Romania, Slovenia, Serbia, Spain, Switzerland, Italy, Turkey, the United Kingdom. These are not all countries of the European Union, but selected countries cover all transport routes from the European Union to Slovakia.

In the paper, a multivariate test of the equality of mean values is used in order to verify the differences among the transportation offers on the individual days of the week and in the respective countries. The test was performed using the Analysis of Variance (ANOVA). With this ANOVA model, we verified whether the mean values of the transportation offer to Slovakia on individual days of the week or in particular countries should be considered the same or they differ significantly, or in other words, whether there exists a significant effect of the day of the week or a country on the level of the transportation supply to Slovakia. The verification of the assumptions of the ANOVA model brings the following results. The normal distribution in the individual subgroups, based on the factor levels, was not confirmed. However, in this case, given the number of measurements in the particular subsets, we consider that this method is robust enough to not meet the assumption of normality because of the central limit theorem (Blanca et al., 2017; Schmider et al., 2010). Homoskedasticity was verified using Levene's test, which resulted in the rejection of the null hypothesis about homoscedasticity. For this reason, we tried to apply a robust Welch test. Using the Welch test, we obtained the same result as in the ANOVA model. In any case, if we used the Kruskal - Wallis test instead of the parametric ANOVA model, we would get the same results as from the parametric ANOVA model. 
All tests were performed at a significance level of 0.05 . If significant differences in the levels of transport supply to Slovakia were found using the ANOVA model, the subsequent multiple comparisons were performed using the Games - Howell post-hoc test in order to find those pairs of days (or countries) in which the mean values of the transportation offer to Slovakia differ significantly. The result of this method will identify those pairs of levels of the investigated factor of the days or countries in which the mean values of the transportation offer to Slovakia differ significantly. The Games - Howell method was chosen as suitable because of the heteroscedasticity of the subgroups (Ruxton \& Beauchamp, 2008).

\section{RESULTS AND DISCUSSION}

In order to be able to verify the dependence of the value of the route utilization coefficient on time, every day in the observed period of one year from each of the 18 countries, the authors identified the proportion of the offered transportations from the total number of entries in the transport databank. Table A in the Annex shows the descriptive characteristics of the return transportation offers to Slovakia from all countries for the individual days of the week.

Based on the number of measurements from all analysed countries on the individual days, it can be seen that the individual days of the week were not evenly covered in the sample during the study period. This was due to the fact that days that would not be considered typical, such as public holidays, Christmas, Easter, etc. have been excluded from the sample. However, given the sufficient sample sizes, this slight imbalance in the samples does not present a problem in evaluating the test results. The mean values of the proportions of the return transportation offer to Slovakia on individual days of the week are represented via the averages. The variability of the transportation offers (quantified by standard deviation and also in relative terms by the coefficient of variation) is quite large on all the days of the week. Still, a comparison of the individual days indicates the same variability of the transportation offers. This variability is probably due to significant differences among the countries, which also has an impact on the discrepancies between the individual values and the average on a given day of the week.

The main aim of this study was, using the ANOVA test, to verify whether there exist significant differences among transportation offers to Slovakia on the individual days of the week, or we can consider the levels of transportation offers to be the same and the day of the week is not the factor that significantly affects their level. Based on the values of the average transportation offers on the particular day of the week (Table A in the Annex), the difference between Tuesday and Thursday is noticeable. In contrast, this difference is at the level of about $1.31 \%$. To verify the statistical significance of these differences, the day of the week was used as the fixed factor in the ANOVA model.

Moreover, the influence of the individual countries to which the transportation is performed on the possibility of performing the return transportation was also of interest in this study. The characteristics of proportions of the return transportations offered from individual countries to Slovakia are listed in Table B in the Annex. All countries were evenly represented in the samples, with 256 values. In this case, based on the average values of the transportation offers in individual countries, it can be assumed that the influence of the country to which the transportation is 
performed will be confirmed and that there exist significant differences among the individual countries. The variability of the values is also relatively high in this case, ranging from almost 40\% in the Czech Republic to more than $143 \%$ in Switzerland. Similarly, as in the case of the impact of the individual days, the country was considered to be another fixed factor in the ANOVA model.

Along with these two factors, their interaction was also included in the model. The results are presented in the form of a univariate general linear model in Table 1.

Tab. 1 - ANOVA model of the effects of the day, country, and their interaction on the transportation offer. Source: own research

\begin{tabular}{|l|l|l|l|l|l|}
\hline \multicolumn{2}{|l|}{ Tests of Between-Subjects Effects } \\
\hline Dependent Variable: transportation offer \\
\hline Source & $\begin{array}{l}\text { Type III Sum } \\
\text { of Squares }\end{array}$ & df & Mean Square & F & Sig. \\
\hline Corrected Model & $1088029.390 \mathrm{a}$ & 125 & 8704.235 & 51.035 & $<.001$ \\
\hline Intercept & 1813558.912 & 1 & 1813558.912 & 10633.396 & $<.001$ \\
\hline Day & 915.563 & 6 & 152.594 & 0.895 & 0.498 \\
\hline Country & 1078843.336 & 17 & 63461.373 & 372.092 & $<.001$ \\
\hline Day * Country & 6014.856 & 102 & 58.969 & 0.346 & $<.001$ \\
\hline Error & 764419.088 & 4482 & 170.553 & & \\
\hline Total & 3673078.000 & 4608 & & & \\
\hline Corrected Total & 1852448.478 & 4607 & & & \\
\hline
\end{tabular}

The coefficient of determination (R-squared) of this model is 0.587 and the adjusted R-squared has a value of 0.576 . The test result indicates that for the individual days of the week, the differences in the offers of transportations to Slovakia are not significant ( $\mathrm{p}$-value $=0.498$ ). Thus, after the analyses of all respective countries included in this study together, there was no evidence of the significant impact of the day of the week on the transportation offers to Slovakia. For this reason, it is not significant for the carriers to change the route utilization coefficient on the individual days of the week in their price calculations.

Moreover, the model in Table 1 shows that the average proportion of the transportation offer to Slovakia is significantly influenced by the country from which the transport is directed ( $\mathrm{p}$-value $<.001)$. The interaction between the day of the week and the country turned out to be significant too (p-value <.001).

Since the assumptions of the ANOVA method were not exactly met, also a more robust Welch F test was applied for the same purpose, which is suitable in case the homoskedasticity assumption is violated. Also, the nonparametric Kruskal - Wallis test was applied. All approaches give the same result. Namely, the significant influence of the country was demonstrated and, conversely, the influence of the day of the week on the level of supply of transport from all countries was not demonstrated. 
Given the results and considering the heteroscedasticity, the authors used a post-hoc Games Howell test to analyse all pairs of countries in order to identify significant differences between the transport offers to Slovakia. The authors summarized the results of the verification in the form of the couples of countries, where within the couple, the differences among the offers of transportation to Slovakia are not significant. These results are listed in Table 2.

Tab. 2 - Post-hoc multiple comparisons by Games - Howell test. Source: own research

\begin{tabular}{|c|c|c|c|c|}
\hline \multicolumn{5}{|c|}{ Multiple Comparisons } \\
\hline \multicolumn{2}{|l|}{ Country } & Mean Difference (I-J) & Std. Error & Sig. \\
\hline Austria & Hungary & 1.70 & 1.401 & 0.999 \\
\hline \multirow{5}{*}{ Belgium } & Bulgaria & -1.64 & 0.537 & 0.183 \\
\hline & France & -0.34 & 0.703 & 1.000 \\
\hline & United Kingdom & -1.82 & 0.702 & 0.466 \\
\hline & Romania & -2.06 & 0.742 & 0.333 \\
\hline & Spain & -0.78 & 0.576 & 0.997 \\
\hline \multirow{6}{*}{ Bulgaria } & France & 1.30 & 0.758 & 0.963 \\
\hline & Germany & -2.73 & 0.878 & 0.157 \\
\hline & United Kingdom & -0.18 & 0.757 & 1.000 \\
\hline & Romania & -0.42 & 0.794 & 1.000 \\
\hline & Serbia & -2.77 & 0.814 & 0.070 \\
\hline & Spain & 0.86 & 0.642 & 0.997 \\
\hline \multirow{4}{*}{ France } & United Kingdom & -1.48 & 0.882 & 0.970 \\
\hline & Luxembourg & 2.55 & 0.770 & 0.089 \\
\hline & Romania & -1.72 & 0.914 & 0.916 \\
\hline & Spain & -0.44 & 0.785 & 1.000 \\
\hline \multirow{4}{*}{ Germany } & United Kingdom & 2.55 & 0.988 & 0.468 \\
\hline & Netherlands & -0.84 & 0.869 & 1.000 \\
\hline & Romania & 2.31 & 1.016 & 0.703 \\
\hline & Serbia & -0.04 & 1.031 & 1.000 \\
\hline \multirow{3}{*}{ United Kingdom } & Romania & -0.24 & 0.914 & 1.000 \\
\hline & Serbia & -2.59 & 0.931 & 0.330 \\
\hline & Spain & 1.04 & 0.785 & 0.998 \\
\hline Italy & Turkey & 1.27 & 1.264 & 1.000 \\
\hline Luxembourg & Switzerland & 1.75 & 0.603 & 0.252 \\
\hline Netherlands & Serbia & 0.80 & 0.804 & 1.000 \\
\hline \multirow{2}{*}{ Romania } & Serbia & -2.34 & 0.961 & 0.578 \\
\hline & Spain & 1.28 & 0.820 & 0.985 \\
\hline
\end{tabular}

In the previous table, the pairs of countries for which the difference between the mean values of the supply of transport to Slovakia was not shown to be significant are listed. Therefore, for 
these countries, the same value of the route utilization coefficient can be assumed. The pairs of countries not included in this table are those for which the difference in the mean values of the transport supply was significant. For these countries, it is quite appropriate to consider setting the route utilization coefficient at different levels.

Based on this research, it can be stated that the route utilization coefficient is not constant in terms of traffic routing. Therefore, the coefficient can be considered as a function of the return transportation $\mathrm{T}_{\mathrm{U}, \mathrm{L}}$

$K=f\left(T_{U, L}\right)$,

where $\mathrm{U}$ represent the countries of the unloading of the goods and $\mathrm{L}$ is the carrier's seat or the starting point of the transportation.

The total costs of the carrier for the performed transportation also correspond to this development. If the carrier has to make a long transfer of the vehicle without a load, higher costs for the transportation must be taken into account. To adjust the costs related to transportation, the route utilization coefficient given by the formula (4) above should be used. The formula for the total transportation-related costs can then be adjusted as follows:

$T C_{T}=V C_{T}+F C_{T}=f\left(v c_{T} ; d_{T}\right) / K+f\left(f c_{D} ; n\right)$

or using (4),

$\mathrm{TC}_{\mathrm{T}}=\mathrm{f}\left(\mathrm{vc}_{\mathrm{T}} ; \mathrm{d}_{\mathrm{T}}\right) /\left(\mathrm{f}\left(\mathrm{T}_{\mathrm{U}, \mathrm{L}}\right)\right)+\mathrm{f}\left(\mathrm{fc}_{\mathrm{D}} ; \mathrm{n}\right)$.

A comparison of the results of this study with the investigations by other authors shows that with the application of the route utilization coefficient in the transport price calculation, the carrier can gain a significant competitive advantage. In their study, Bokor \& Markovits-Somogyi (2015) preferred to use a coefficient value of 0.5. In research by Bao \& Mundy (2018), Drozdziel \& Piasecki (1995), Gnap (2002), and Engholm et al. (2020), the values of the coefficient K within the range of 0.8 to 0.9 are used. A comparison of the results of the application of this coefficient for specific countries shows the differences in the transport prices. These differences are particularly visible for those countries where the level of transport supply is very low, such as France and Luxembourg. As the average daily supply of transport from these countries to Slovakia is low, from France on average $8.78 \%$ of offered transport, from Luxembourg $6.23 \%$, with a very high probability, the vehicle will return to Slovakia empty. This fact will be greatly reflected in pricing. If the carrier uses the constant value $K=0.8$ proposed by the authors in the mentioned studies, the calculations may be misleading and the profit will not be as high as had been estimated. A loss may even be incurred, although the transaction for the transport was assumed to be profitable when the contract of carriage was concluded. If the carrier applies the methodology of setting the level of $\mathrm{K}$ as proposed in this study, setting the coefficient to the level $\mathrm{K}=0.5+0.0878-0.05=0.5378$ where 0.5 is the coefficient for the route to the France and 0.05 is the correction due to a transfer between the place of unloading of the goods and the place of further loading of the goods, this calculation will provide them with better cost guidance. Therefore, using the variable route utilization coefficient, the carrier can identify inefficient transportation to a country with a low return offer and adjust the offered transportation price at which the carrier is willing to carry out the transportation. 
The opposite is also true. Transportation to some countries which appear to be inefficient in terms of a regular route utilization coefficient may be effective if a sufficient return offer identified by a variable coefficient is also figured in. Examples are the Czech Republic and Poland, where the supply of transport to Slovakia is the highest, averaging $59.52 \%$ and $51.94 \%$, respectively. From these two countries, therefore, a higher supply of consignments than free vehicles exists, so there is a low probability that the vehicle will make the return route empty. Instead of the constant value $\mathrm{K}=0.8$ proposed by the previously mentioned authors, it is appropriate to use the level $\mathrm{K}=0.95$ proposed in this study (where 0.05 is again a correction due to the transfer of the vehicle between the place of unloading the goods and a load of new goods). Applying the value of the coefficient set in this way will bring the price competitiveness to the carriers, as the price determined in this way will be lower than by using a constant coefficient, yet sufficient for the carrier to cover the costs. Of course, it is possible to adjust the efficiency by the increasing the price, i.e. the customer pays for the return transportation of the empty vehicle as well.

To summarize, the results of this analysis show that it is economically more advantageous and a more accurate calculation for the carrier to use a route utilization coefficient set concerning the country from which the transport is directed. It can be assumed that the same conclusions would apply to transport to countries other than Slovakia. Our research did not show that the route utilization coefficient is dependent on the date of the transportation. If the transportation takes place a specific country, the transport operator can use the same value of the route utilization coefficient in the cost calculations throughout the whole week.

\section{CONCLUSION}

International road freight transport operators currently operate in the common market of the European Union in ways that they can all perform international transportations under the same conditions. On the one hand, the entire EU market has been opened up for the carriers from individual European countries, but competition has also increased significantly. A higher competitive environment raises the demand for more accurate cost calculations. In the analysis of the cost calculation procedures, the authors identified a blank space for the possibility of data specification for the decision-making process of the carriers. The authors found that in the past the authors preferred cost calculations divided into direct and indirect costs. Currently, cost calculations subdivided into variable and fixed costs are preferred. However, in the studies published so far by other authors, no approach has been found for the use of the route utilization coefficient as a variable value within the process of the cost calculations. All the analysed resources consider this coefficient as a constant value ranging from the interval (0.1). Therefore, in this paper, the authors conducted extensive research on the data of 43,000 transportation companies offering transportation in 19 countries through the entries of the transportation offers and accessible vehicles in transportation databases. Although the current calculations use a constant value of the route utilization coefficient, this study has shown that such a procedure is not the best one for maintaining the competitiveness of the carrier in specific markets. Based on the analysis of 750,000 entries on a daily basis within the period of one year, we identified the dependence of the route utilization coefficient upon the country of the transportation routing. The authors also researched the dependence of the route utilization coefficient with regard to the 
particular day of the week in which transport is commenced. However, the effect of this factor on the coefficient was not confirmed.

The authors are aware that there are special transportation types for which the application of the route utilization coefficient is problematic because it is not possible to perform return transportation in such vehicles. This applies in particular to tank vehicles intended for the transport of dangerous goods or foodstuffs. In the paper, the authors have dealt with common flatbed trucks.

In the future, the authors recommend focusing research on the identification of the route utilization coefficient modification for refrigerated trucks, for which it is also possible to perform return transportations in a limited way. As the impact of the interaction between days and countries has also proved to be significant, the carrier can adjust the route utilization coefficient even more precisely based on a combination of these two factors. But if the carrier wanted to use the pairs created in Tab. 2 to design common levels of the coefficient $\mathrm{K}$ for them, the problem would be that these pairs are not disjunct, which can be seen as a limitation of our study. Therefore, the future direction of this study lies in the creation of clusters of countries for which it is appropriate to propose common route utilization coefficients $\mathrm{K}$. It would also be beneficial to measure the coefficient in actual conditions and to estimate the accuracy of the coefficient obtained from the methodology proposed in this study. Another possible limit of the study may be the fact that data for all EU countries were not used for the analysis. Nevertheless, the obtained results can still be considered highly applicable and generalizable.

Acknowledgements: This paper was developed through support from the project: MŠVVŠ SR VEGA No. 1/0245/20 POLIAK, M.: Identification of the impact of a change in transportrelated legislation on the competitiveness of carriers and carriage safety

\section{References}

1. Albalate, D., Bel, G., \& Fageda, X. (2015). Competition and cooperation between high-speed rail and air transportation services in Europe. Journal of Transport Geography, 42, 166-174. https://doi.org/10.1016/j.jtrangeo.2014.07.003

2. Askari, S., \& Peiravian, F. (2019). Public transportation quality of service: Factors, models, and applications. Transport Reviews, 39 (4), 558-560. https://doi.org/10.1080/01441647.2018.1531083

3. Avetisyan, M., Heatwole, N., Rose, A., \& Roberts, B. (2015). Competitiveness and macroeconomic impacts of reduced wait times at U.S. land freight border crossings. Transportation Research Part A: Policy and Practice, 78, 84-101. https://doi.org/10.1016/j. tra.2015.04.027

4. Baller, A. C., Dabia, S., Dullaert, W. E. H., \& Vigo, D. (2019). The Dynamic-Demand Joint Replenishment Problem with Approximated Transportation Costs. European Journal of Operational Research, 276 (3), 1013-1033. https://doi.org/10.1016/j.ejor.2019.01.070

5. Bao, K., \& Mundy, R. A. (2018). Emerging Freight Truck Technologies: Effects on Relative Freight Costs (s. 26) [Final report]. The Midwest Transportation Center. https://rosap.ntl.bts. gov/view/dot/36218 
6. Blanca, M. J., Alarcón, R., \& Arnau, J. (2017). Non-normal data: Is ANOVA still a valid option? Psicothema, 29 (4), 552-557. https://doi.org/10.7334/psicothema2016.383

7. Bokor, Z., \& Markovits-Somogyi, R. (2015). Improved Cost Management at Small and Medium-Sized Road Transport Companies: Case Hungary. Promet - Traffice Transportation, 27 (5), 417-428. https://doi.org/10.7307/ptt.v27i5.1719

8. Drozdziel, P., \& Piasecki, S. (1995). Study of the method of assessing the economic efficiency of exploitation cars in a transport company. Folia Societatis Scientarium Lublinensis, 60-66.

9. Engholm, A., Pernestal, A., \& Kristoffersson, I. (2020). Cost Analysis of Driverless Truck Operations. Transportation Research Record, 2674 (9), 511-524. https://doi. org $/ 10.1177 / 0361198120930228$

10. Regulation (EU) 2020/1054 of the European Parliament and of the Council of 15 July 2020 amending Regulation (EC) No 561/2006 as regards minimum requirements on maximum daily and weekly driving times, minimum breaks and daily and weekly rest periods and Regulation (EU) No 165/2014 as regards positioning by means of tachographs, No. 32020R1054, L 249 Official Journal of the European Union 1 (2020). http://data.europa.eu/ eli/reg/2020/1054/oj/eng

11. Ferrari, P. (2016). Instability and dynamic cost elasticities in freight transport systems. Transport Policy, 49, 226-233. https://doi.org/10.1016/j.tranpol.2016.05.008

12. Forootani, A., Tipaldi, M., Zarch, M. G., Liuzza, D., \& Glielmo, L. (2019). Modelling and solving resource allocation problems via a dynamic programming approach. International Journal of Control, 94 (6), 1544-1555. https://doi.org/10.1080/00207179.2019.1661521

13. Gasparik, J., Stopka, O., \& Peceny, L. (2015). Quality Evaluation in Regional Passenger Rail Transport. Naše More, 62 (3), 114-118. https://doi.org/10.17818/nm/2015/si5

14. Gnap, J. (2002). Kalkulácia vlastných nákladov a tvorba ceny v cestnej doprave. Zilina: Zilinská univerzita v Ziline.

15. Gnap, J., Konecny, V., \& Vajran, P. (2018). Research on Relationship between Freight Transport Performance and GDP in Slovakia and EU Countries. Naše more, 65 (1), 32-39. https://doi.org/10.17818/NM/2018/1.5

16. Jourquin, B. (2019). Estimating Elasticities for Freight Transport Using a Network Model: An Applied Methodological Framework. Journal of Transportation Technologies, 9 (1), 1-13. https://doi. org/10.4236/jtts.2019.91001

17. Jourquin, B., \& Beuthe, M. (2019). Cost, transit time and speed elasticity calculations for the European continental freight transport. Transport Policy, 83, 1-12. https://doi.org/10.1016/j. tranpol.2019.08.009

18. Kedzior-Laskowska, M. (2019). Economic attributes of quality and competitiveness on the market of road freight transport services. Ekonomia i Prawo, 18 (4), 441-457.

19. Kliestik, T., Misankova, M., Valaskova, K., \& Svabova, L. (2018). Bankruptcy Prevention: New Effort to Reflect on Legal and Social Changes. Science and Engineering Ethics, 24 (2), 791-803. https://doi.org/10.1007/s11948-017-9912-4

20. Kovacs, G. (2017). First Cost Calculation Methods for Road Freight Transport Activity. Transport and Telecommunication Journal, 18 (2), 107-117. https://doi.org/10.1515/ttj-2017-0010 
21. Krasnyanskiy, M., \& Penshin, N. (2016). Quality criteria when assessing competitiveness in road transport services. Transport Problems, 11 (4), 15-20. https://doi.org/10.20858/ tp.2016.11.4.2

22. Lada, A. N., Sazonov, V. V., \& Skobelev, P. O. (2016). Method for Transportation Cost Calculation on the Basis of Full Cycle (Round Trip). Indian Journal of Science and Technology, 9 (20), 1-6. https://doi.org/10.17485/ijst/2016/v9i20/94478

23. Lai, Y.-B. (2010). The political economy of capital market integration and tax competition. European Journal of Political Economy, 26 (4), 475-487. https://doi.org/10.1016/j. ejpoleco.2010.02.001

24. Litman, T. (2019). How Prices and Other Factors Affect Travel Behavior. Victoria Transport Policy Institute. Retrieved from: https://www.vtpi.org/elasticities.pdf

25. McLennan, A. (1984). Price dispersion and incomplete learning in the long run. Journal of Economic Dynamics and Control, 7 (3), 331-347. https://doi.org/10.1016/0165-1889(84)90023-X

26. Mitsakis, E., Iordanopoulos, P., Aifadopoulou, G., Tyrinopoulos, Y., \& Chatziathanasiou, M. (2015). Deployment of Intelligent Transportation Systems in South East Europe: Current Status and Future Prospects. Transportation Research Record, 2489 (1), 39-48. https://doi. org $/ 10.3141 / 2489-05$

27. Nowak, J., Mrňová, Z., Tichá, A., Tichý, J., \& Vázlerová, M. (2019). Differences in the Cost Calculation for Construction Work, Road Transport and Water Supply. IOP Conference Series: Materials Science and Engineering, 603 (3), 032086. https://doi.org/10.1088/1757899X/603/3/032086

28. Osterloh, S., \& Debus, M. (2012). Partisan politics in corporate taxation. European Journal of Political Economy, 28 (2), 192-207. https://doi.org/10.1016/j.ejpoleco.2011.11.002

29. Osterloh, S., \& Heinemann, F. (2013). The political economy of corporate tax harmonization - Why do European politicians (dis)like minimum tax rates? European Journal of Political Economy, 29, 18-37. https://doi.org/10.1016/j.ejpoleco.2012.09.002

30. Poliak, M. (2013). The Relationship with Reasonable Profit and Risk in Public Passenger Transport in Slovakia. Ekonomicky časopis, 61 (2), 206-220.

31. Ross, D. F. (2015). Distribution Planning and Control: Managing in the Era of Supply Chain Management (3rd Ed.). New York: Springer US.

32. Rothengatter, W. (2019). Megaprojects in transportation networks. Transport Policy, 75 (3), 1-15.

33. Rotondo, E. (2013). The legal effect of EU Regulations. Computer Law \& Security Review, 29 (4), 437-445. https://doi.org/10.1016/j.clsr.2013.05.003

34. Rushton, A., Croucher, P., \& Baker, P. (2010). The handbook of logistics \& distribution management. London: Kogan Page Limited.

35. Ruxton, G. D., \& Beauchamp, G. (2008). Time for some a priori thinking about post hoc testing. Behavioral Ecology, 19 (3), 690-693. https://doi.org/10.1093/beheco/arn020

36. Schmider, E., Ziegler, M., Danay, E., Beyer, L., \& Bühner, M. (2010). Is It Really Robust? Methodology, 6 (4), 147-151. https://doi.org/10.1027/1614-2241/a000016 
37. Svabova, L., \& Durica, M. (2016). A closer view of the statistical methods globally used in bankruptcy prediction of companies. Globalization and its socio-economic consequences : 16th international scientific conference: Proceedings, Part V., 2174-2181.

38. Svabova, L., Michalkova, L., Durica, M., \& Nica, E. (2020). Business Failure Prediction for Slovak Small and Medium-Sized Companies. Sustainability, 12 (11), 4572. https://doi. $\operatorname{org} / 10.3390 /$ su12114572

39. Timocom. (2020). TIMOCOM transport barometer. Timocom. Retrieved from https://www. timocom.co.uk/services/transport-barometer

40. Trigaux, D., Wijnants, L., De Troyer, F., \& Allacker, K. (2017). Life cycle assessment and life cycle costing of road infrastructure in residential neighbourhoods. The International Journal of Life Cycle Assessment, 22 (6), 938-951. https://doi.org/10.1007/s11367-016-1190-x

41. Turner, S., \& Park, E. S. (2008). Incomplete Archived Data of Intelligent Transportation Systems for Calculation of Annual Average Traffic Statistics: What Level of Missing Data Causes Problems? Transportation Research Record, 2049 (1), 1-13. https://doi.org/10.3141/204901

42. Vaishya, S. R., \& Sarkar, V. (2019). Accurate loss modelling in the DCOPF calculation for power markets via static piecewise linear loss approximation based upon line loading classification. Electric Power Systems Research, 170, 150-157. https://doi.org/10.1016/j. epsr.2019.01.015

43. Valaskova, K., Kliestik, T., \& Kovacova, M. (2018). Management of financial risks in Slovak enterprises using regression analysis. Oeconomia Copernicana, 9 (1), 105-121. https://doi. org/10.24136/oc.2018.006

44. Xie, X.-F., \& Wang, Z. J. (2018). Combined traffic control and route choice optimization for traffic networks with disruptive changes. Transportmetrica B: Transport Dynamics, 7 (1), 814-833. https://doi.org/10.1080/21680566.2018.1517059

\section{Contact information}

prof. Ing. Milos Poliak, PhD.

University of Žilina

Faculty of Operation and Economics of Transport and Communications

Department of Road and Urban Transport

Univerzitná 1, 01026 Žilina,

Slovak Republic

E-mail:milos.poliak@fpedas.uniza.sk.

ORCID: 0000-0002-9149-2439

Ing. Adela Poliakova, PhD., EUR ING

University of Žilina

Faculty of Operation and Economics of Transport and Communications

Department of Economics

Univerzitná 1, 01026 Žilina,

Slovak Republic

E-mail:adela.poliakova@,fpedas.uniza.sk

ORCID: 0000-0002-9971-9589 
doc. RNDr. Lucia Svabova, PhD.

University of Žilina

Faculty of Operation and Economics of Transport and Communications

Department of Economics

Univerzitná 1, 01026 Žilina,

Slovak Republic

E-mail: lucia.svabova@fpedas.uniza.sk

ORCID: 0000-0002-4722-4103

prof. Ing. Natalia Aleksandrovna Zhuravleva, PhD.

Petersburg State Transport University

Transportation Economics Department

Moskouskij prospect, 9

St. Petersburg 190031,

Russian Federation

Email: zhuravleva_na@mail.ru

ORCID:0000-0003-3566-9225

prof. univ. dr. Elvira Nica

Bucharest University of Economic Studies

Faculty of Administration and Public Management

Piata Romană 6,

Bucharest 010374,

Romania

Email:Elvira.nica@ase.ro

ORCID: 0000-0002-8368-8028

\section{APPENDIX}

Tab. A - Proportion of return transportations offered from all analysed countries to Slovakia depending on the specific day of the week in (\%). Source: own research

\begin{tabular}{|l|l|l|l|l|l|l|}
\hline Day & N & Mean $(\%)$ & $\begin{array}{l}\text { Std. } \\
\text { Deviation } \\
(\%)\end{array}$ & $\begin{array}{l}\text { Coeff. of } \\
\text { Variation } \\
(\%)\end{array}$ & $\begin{array}{l}\text { Minimum } \\
(\%)\end{array}$ & $\begin{array}{l}\text { Maximum } \\
(\%)\end{array}$ \\
\hline Monday & 594 & 19.77 & 20.145 & 101.90 & 2 & 87 \\
\hline Tuesday & 630 & 19.22 & 20.111 & 104.64 & 2 & 87 \\
\hline Wednesday & 684 & 19.98 & 20.544 & 102.82 & 2 & 86 \\
\hline Thursday & 684 & 20.53 & 20.52 & 99.95 & 2 & 87 \\
\hline Friday & 666 & 20.41 & 19.983 & 97.91 & 2 & 86 \\
\hline Saturday & 648 & 19.41 & 19.183 & 98.83 & 2 & 81 \\
\hline Sunday & 702 & 19.75 & 19.878 & 100.65 & 2 & 83 \\
\hline Total & 4608 & 19.88 & 20.052 & 100.87 & 2 & 87 \\
\hline
\end{tabular}


Tab. B - Characteristics of proportions of the return transportations offered from individual countries to Slovakia in (\%). Source: own research

\begin{tabular}{|c|c|c|c|c|c|c|}
\hline Country & $\mathrm{N}$ & Mean (\%) & $\begin{array}{l}\text { Std. Deviation } \\
(\%)\end{array}$ & $\begin{array}{l}\text { Coeff. of } \\
\text { Variation } \\
(\%)\end{array}$ & $\begin{array}{l}\text { Minimum } \\
(\%)\end{array}$ & $\begin{array}{l}\text { Maximum } \\
(\%)\end{array}$ \\
\hline Austria & 256 & 29.7 & 16.081 & 54.14 & 5 & 85 \\
\hline Belgium & 256 & 8.45 & 5.168 & 61.16 & 2 & 27 \\
\hline Bulgaria & 256 & 10.08 & 6.873 & 68.18 & 2 & 32 \\
\hline $\begin{array}{l}\text { Czech } \\
\text { Republic }\end{array}$ & 256 & 59.52 & 23.626 & 39.69 & 11 & 87 \\
\hline France & 256 & 8.78 & 9.984 & 113.71 & 2 & 74 \\
\hline Germany & 256 & 12.81 & 12.251 & 95.64 & 2 & 83 \\
\hline $\begin{array}{l}\text { United } \\
\text { Kingdom }\end{array}$ & 256 & 10.26 & 9.978 & 97.25 & 2 & 76 \\
\hline Hungary & 256 & 28.01 & 15.615 & 55.75 & 3 & 84 \\
\hline Italy & 256 & 23.7 & 10.993 & 46.38 & 8 & 71 \\
\hline Luxembourg & 256 & 6.23 & 7.214 & 115.79 & 2 & 43 \\
\hline Netherlands & 256 & 13.65 & 6.563 & 48.08 & 2 & 34 \\
\hline Poland & 256 & 51.94 & 20.825 & 40.09 & 11 & 80 \\
\hline Romania & 256 & 10.5 & 10.683 & 101.74 & 2 & 74 \\
\hline Serbia & 256 & 12.85 & 11.057 & 86.05 & 2 & 55 \\
\hline Slovenia & 256 & 35.18 & 16.359 & 46.50 & 2 & 65 \\
\hline Spain & 256 & 9.22 & 7.624 & 82.69 & 2 & 50 \\
\hline Switzerland & 256 & 4.47 & 6.412 & 143.45 & 2 & 54 \\
\hline Turkey & 256 & 22.43 & 16.974 & 75.68 & 2 & 77 \\
\hline Total & 4608 & 19.88 & 20.052 & 100.87 & 2 & 87 \\
\hline
\end{tabular}

